\title{
TRANSPLANTATION OF PREIMPLANTATION HAMSTER EMBRYOS
}

\author{
A. SATO* AND R. YANAGIMACHI \\ Department of Anatomy and Reproductive Biology, \\ University of Hawaii School of Medicine, Honolulu, Hawaii 96822, U.S.A.
}

(Received 21st February 1972, accepted 13th March 1972)

Since Heape (1890) first succeeded in transplanting rabbit embryos (four-cell stage), the transplantation of fertilized eggs and preimplantation embryos of laboratory animals has been progressively more successful (for review and bibliography, see Chang \& Pickworth, 1969; Adams \& Abbott, 1971), though few studies seem to have been made on the transplantation of hamster embryos. Blaha (1964) reported that $49.2 \%$ of six- to eight-cell embryos from young

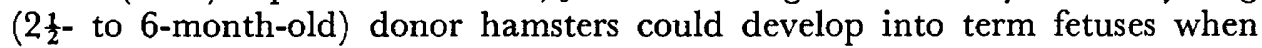
transplanted into young recipients, but that only $8.3 \%$ of embryos of the same developmental stage developed into fetuses when transplanted into old (14- to 10-month-old) recipients. The incidence of successful fetal development was also very low $(4.5 \%)$ when the embryos from old donors were transplanted into young recipients. Orsini \& Psychoyos (1965) transplanted hamster blastocysts into progesterone-treated females which had been previously ovariectomized, and found that some of the embryos could develop into live fetuses ( 7 to 12 days). According to Yang (cited from Chang \& Pickworth, 1969), 49 to $54 \%$ of 3- to 4-day preimplantation hamster embryos could develop into fetuses following transplantation, when the reproductive phases of the donor and recipient females were synchronized. Asynchronous transplantation (Day-3 embryos to Day-4 uteri or Day-4 embryos to Day-3 uteri) resulted in a lower rate $(14$ to $35 \%)$ of successful fetal development. This communication reports the results of synchronous transplantation of preimplantation hamster embryos, including transplantation of one- and two-cell embryos.

Female golden hamsters were raised in an air-conditioned room with a 12-hr light cycle (light, from 06.00 hours until 18.00 hours) and used in experiments when they weighed 90 to $120 \mathrm{~g}$ ( 2 to 3 months after birth). The oestrous cycle of each female was determined according to Orsini (1961), except that the day on which postoestrous vaginal discharge occurred was taken as the lst day of the oestrous cycle. Between 21.00 hours and 22.00 hours on the 4th day of the cycle (when the animals were in heat), prospective recipient females were given mechanical vaginal/cervical stimulation in order to induce pseudopregnancy (Diamond \& Yanagimachi, 1968). Females to be used as donors were mated with fertile males in the evening of the same day. The day following mating or vaginal stimulation was designated Day 1 of pregnancy or pseudopregnancy.

* Permanent address: Biological Laboratory, Komazawa College, Tomakomai, Hokkaido 053, Japan. 
Text-figure 1 shows the time of major events and the developmental stages of the embryos during the first 4 days of pregnancy.

The oviducts and uteri excised from the donors were individually flushed with $0.2 \mathrm{ml}$ of sterile TC-199 medium (Difco Lab.). Those embryos recovered were rinsed twice with TC-199 and stored in the medium for no longer than $30 \mathrm{~min}$ before transfer to recipient females. Recipient females were anaesthetized by injection of sodium pentobarbitone $(4.5 \mathrm{mg} / \mathrm{female})$ supplemented with methoxyfluran vapour (Metofan, Dow Chem.), and their oviducts and uteri were exposed by dorsolateral incisions. Three to five embryos were drawn into a

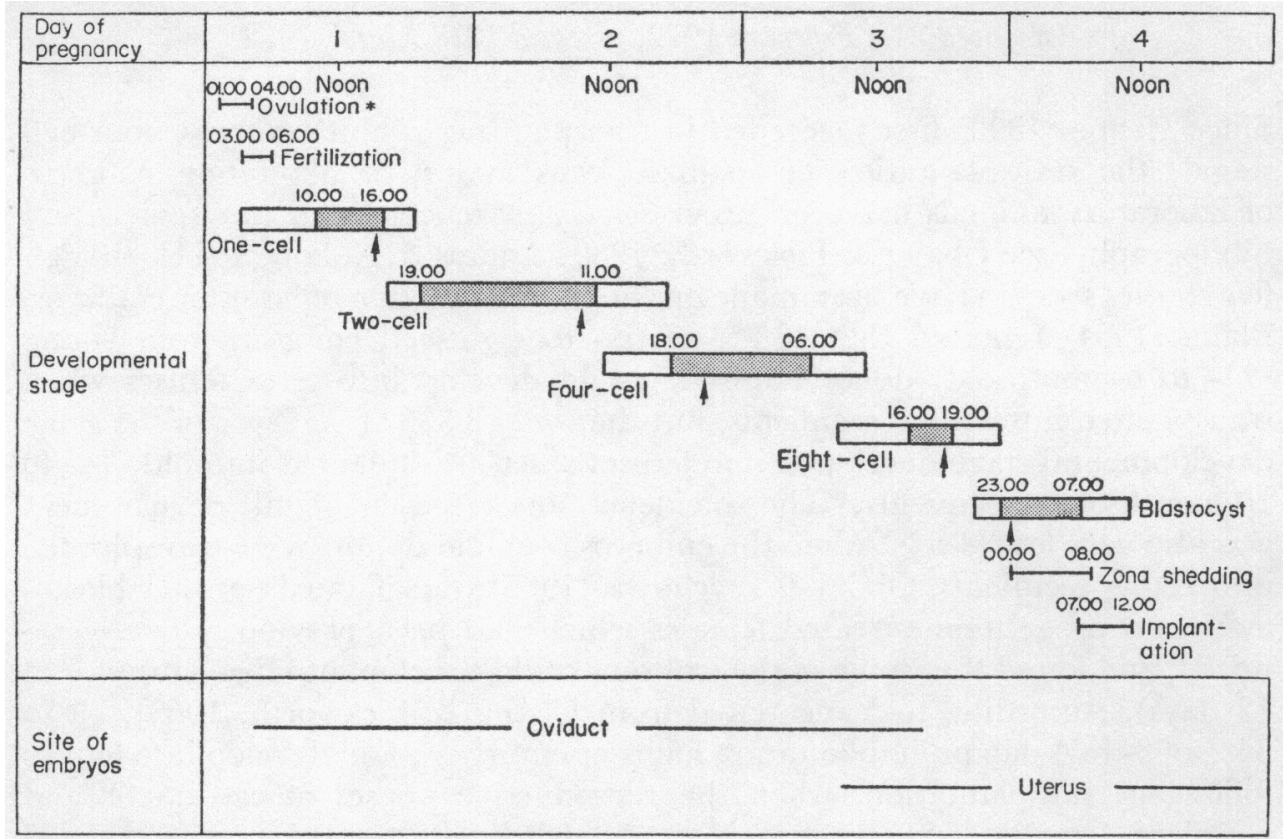

Text-Fig. 1. Major events and developmental stages of hamster embryos during the first 4 days of pregnancy. Columns illustrate times during which respective embryos can be recovered: the optimum recovery times are indicated by dotted columns. Arrows indicate the times when the donors were killed and the embryos recovered were transferred to the recipients. * Cited from Austin (1956).

capillary pipette $(0.1 \mathrm{~mm}$ i.d. at the tip). The pipette was inserted into either (1) the ampullary portion of the oviduct through the infundibulum, or (2) the uterine lumen through a needle puncture slightly below the uterotubal junction. The fluid containing the embryos was injected into the lumen of the oviduct or uterus by gently blowing through a rubber tube attached to the pipette. After each operation, the capillary was checked with a dissecting microscope to ascertain whether all the embryos had indeed been transferred. The total volume of TC-199 plus embryos at the time of transfer was approximately $0.02 \mathrm{~mm}^{3}$. All procedures involved in the handling of embryos were performed at room temperature $\left(25^{\circ} \mathrm{C}\right)$. Recipient females were individually caged after surgery, killed on Day 14 of pregnancy, and examined for the presence of (1) live fetuses, (2) resorbing fetuses and (3) placental remnants. The presence of placental remnants was taken as an indication that the embryos had implanted 
in the uterus but had died sometime thereafter. Females showing no sign of fetuses or placental remnants in their uteri were considered non-pregnant.

The results (Table 1) showed that none of fifteen females receiving one- and two-cell embryos became pregnant, while 50 to $100 \%$ of the females receiving four-cell or older embryos did become pregnant. As will be seen from Table 1, the best fetal development occurred when the embryos were at the blastocyst stage at the time of transfer into the uteri. It appears from the data that over $80 \%$ of the blastocysts transferred implanted successfully, and about $70 \%$ of these developed normally. To discover whether transplanted blastocysts can develop beyond Day 14 of pregnancy, sixteen blastocysts from two donors were

\section{TABLE 1}

PREGNANCY AND FETAL DEVELOPMENT IN HAMSTERS FOLLOWING SYNCHRONOUS TRANSPLANTATION OF PREIMPLANTATION HAMSTER EMBRYOS: EXAMINED ON DAY 14 OF PREGNANCY

\begin{tabular}{|c|c|c|c|c|c|c|c|c|}
\hline \multicolumn{2}{|l|}{ Embryos transferred } & \multirow{2}{*}{$\begin{array}{c}\text { Site } \\
\text { of } \\
\text { embryo } \\
\text { transfer }\end{array}$} & \multicolumn{2}{|c|}{$\underset{\text { recipients* }}{\text { No of }}$} & \multicolumn{4}{|c|}{$\begin{array}{c}\text { No. and } \% \text { (against total no. of embryos } \\
\text { transferred) of: }\end{array}$} \\
\hline $\begin{array}{l}\text { Stage (estimated no. of } \\
\quad h r \text { after ovulation) }\end{array}$ & $\begin{array}{c}\text { Total } \\
\text { no. }\end{array}$ & & Total & Pregnant & $\begin{array}{c}\text { Live } \\
\text { fetuses } \dagger\end{array}$ & $\begin{array}{l}\text { Resorbing } \\
\text { fetuses }\end{array}$ & $\begin{array}{l}\text { Placental } \\
\text { remnants }\end{array}$ & $\begin{array}{l}\text { Total fetuses } \\
\text { and remnants }\end{array}$ \\
\hline One-cell (11 to 14$)$ & 52 & Oviduct & 7 & $\mathbf{0}$ & 0 & 0 & 0 & 0 \\
\hline Two-cell (30 to 33$)$ & 57 & Oviduct & 8 & 0 & 0 & 0 & 0 & 0 \\
\hline Four-cell ( 42 to 45 ) & 64 & Uterus & 8 & 4 & $19(29.6)$ & 0 & $4 \quad(6 \cdot 3)$ & $23(35.9)$ \\
\hline Eight-cell ( 62 to 65 ) & 62 & Uterus & 8 & 7 & $30(48.4)$ & $5(8 \cdot 0)$ & $6 \quad(9 \cdot 7)$ & $41(66 \cdot 1)$ \\
\hline Blastocyst (67 to 70 ) & 80 & Uterus & 8 & 8 & $46(57 \cdot 5)$ & $2(2.5)$ & $18(22 \cdot 5)$ & $66(82.5)$ \\
\hline
\end{tabular}

* Animals showing postoestrous discharge on Day 5 were not considered pseudopregnant and therefore were not included in these data.

$\dagger$ Normal size, heart beating.

transplanted to two recipients. These recipients delivered nine live young on Days 16 to 17, all of which grew into healthy, fertile adults (five males and four females). Similar experiments with sixteen four-cell and sixteen eight-cell embryos showed that $31.3 \%$ (five/sixteen) and $37.5 \%$ (six/sixteen) of these embryos, respectively, were delivered and subsequently developed into healthy adults.

The importance of synchronization of the reproductive phases of donor and recipient for successful development of transplanted embryos has been well documented. Generally, the highest survival rates of the embryos result when the embryos are transferred to recipients whose reproductive phases are synchronized with or are slightly earlier than those of the donors (Chang \& Pickworth, 1969). The golden hamster seems to be no exception to this general rule (Yang; cited from Chang \& Pickworth, 1969). The results of our study confirm Yang's finding that older embryos (4-day embryos, probably blastocysts) can survive better after transfer than younger embryos (3-day embryos, probably four- or eight-cell). Although we do not know the exact parameters which Yang used for evaluation of successful fetal development, the success following transplantation of 4-day embryos (blastocysts) in our experiments $(60 \%)$ seems to be about the same as in his experiments (54\%). The failure of 
implantation of the embryos transplanted at one- and two-cell stages was disappointing. In a separate series of experiments, we have shown that all such embryos failed to undergo cleavage and started to degenerate while they were in the oviducts. This may have been due either to the medium used for handling the embryos or to some kind of shock given the recipients during surgery. Perhaps, if we could improve the medium for handling the embryos and discover the best sites for transfer and surgical techniques, embryos transferred at a very early stage of development might well develop into normal fetuses or young.

This study was supported by grants from the Ford Foundation, the Population Council and the U.S. Public Health Service (HD-03402 and HD-02066). We are grateful to Dr V. J. DeFeo, Dr J. M. Cummins and Mrs C. A. Mahi for their consultation and assistance in preparation of the manuscript.

\section{REFERENCES}

Adams, G. E. \& Аввотт, M. (1971) Bibliography on recovery and transfer of mammalian eggs and ovarian transplantation. Biblphy Reprod., Bibl. No. 45.

Austin, C. R. (1956) Ovulation, fertilization, and early cleavage in the hamster (Mesocricetus auratus). Fl R. microsc. Soc. 75, 141.

BLAна, G. G. (1964) Effect of age of the donor and recipient on the development of transferred golden hamster ova. Anat. Rec. 150, 413.

Chanc, M. G. \& Pickworth, S. (1969) Egg transfer in the laboratory animal. In: The Mammalian Oviduct, p. 389. Eds E. S. E. Hafez and R. J. Blandau. University of Chicago Press.

Diamond, M. \& Yanagimachi, R. (1968) Induction of pseudopregnancy in the golden hamster. $\mathcal{F}$. Reprod. Fert. 17, 165.

Heape, W. (1890) Preliminary note on the transplantation and growth of mammalian ova within uterine foster mother. Proc. R. Soc. B, 48, 457.

Orsini, M. (1961) The external vaginal phenomena characterizing the stages of the estrous cycle, pregnancy, pseudopregnancy, lactation, and the anestrous hamster. Mesocricetus auratus Waterhouse. Proc. Anim. Care Panel, 11, 193.

Orsini, M. W. \& Psychoyos, A. (1965) Implantation of blastocysts transferred into progesterone treated virgin hamsters previously ovariectomized. F. Reprod. Fert. 10, 300. 